\title{
Synthesis and Structural Characterization of a New Tetranuclear Nickel(II) Sulfato Complex Containing the Anionic Form of Di-2-Pyridyl Ketone Oxime
}

\author{
Eleni Moushi, ${ }^{1}$ Constantinos G. Efthymiou, ${ }^{2}$ Spyros P. Perlepes, ${ }^{3}$ \\ and Constantina Papatriantafyllopoulou ${ }^{2,3}$ \\ ${ }^{1}$ Department of Chemistry, University of Cyprus, 1678 Nicosia, Cyprus \\ ${ }^{2}$ Department of Chemistry, University of Florida, Gainesville, FL 32611-7200, USA \\ ${ }^{3}$ Department of Chemistry, University of Patras, 26504 Patras, Greece \\ Correspondence should be addressed to Constantina Papatriantafyllopoulou,cpapat@chem.ufl.edu
}

Received 7 December 2010; Accepted 26 January 2011

Academic Editor: Daniel L. Reger

Copyright ( $) 2011$ Eleni Moushi et al. This is an open access article distributed under the Creative Commons Attribution License, which permits unrestricted use, distribution, and reproduction in any medium, provided the original work is properly cited.

The preparation and crystal structure of a tetranuclear $\mathrm{Ni}$ (II) sulfato cluster containing the anion of di-2-pyridyl ketone oxime, (py) ${ }_{2} \mathrm{CNO}^{-}$, are reported. Treatment of $\mathrm{NiSO}_{4} \cdot 6 \mathrm{H}_{2} \mathrm{O}$ with one equivalent of $(\mathrm{py})_{2} \mathrm{CNOH}$ and one equivalent of $\mathrm{NEt}_{3}$ in $\mathrm{MeOH}$ leads to the compound $\left[\mathrm{Ni}_{4}\left\{(\mathrm{py})_{2} \mathrm{CNO}\right\}_{4}\left(\mathrm{SO}_{4}\right)_{2}(\mathrm{MeOH})_{4}\right](\mathbf{1})$ in moderate yield. The metal ions are linked together by two 3.2111 and two 2.1110 (Harris notation) (py) ${ }_{2} \mathrm{CNO}^{-}$ligands, as well as two $2.1100 \mathrm{SO}_{4}{ }^{2-}$ ions to create a rare metallacrown-type (12MC-4) ring. Strong H-bond intermolecular interactions in $\mathbf{1}$ lead to the formation of a $1 \mathrm{D}$ chain along the $c$ axis. Characteristic IR bands are discussed in terms of the known structure of $\mathbf{1}$.

\section{Introduction}

There is currently a renewed interest in the coordination chemistry of oximes [1-20]. 2-pyridyl oximes (Scheme 1) are popular ligands in coordination chemistry [21-36]. The anions of these molecules are versatile ligands for a variety of research objectives, including $\mu_{2}$ and $\mu_{3}$ behaviour [21, $22]$; the activation of 2-pyridyl oximes by $3 \mathrm{~d}$-metal centers towards further reactions is also becoming a fruitful area of research $[21,22,26]$. The majority of the metal complexes of these ligands have been prepared in the last 15 years and much of their chemistry remains to be explored in more detail [22].

We have been exploring "ligand blend" reactions involving carboxylates $\left(\mathrm{R}^{\prime} \mathrm{CO}_{2}^{-}\right)$and various 2-pyridyloximates with (ternary "ligand blends") or without (binary "ligand blends") additional inorganic monoanions $\left(\mathrm{Cl}^{-}, \mathrm{Br}^{-}, \mathrm{NO}_{3}{ }^{-}\right.$, $\mathrm{N}_{3}{ }^{-}, \mathrm{SCN}^{-}$) as a means to high-nuclearity species. The presence of a deprotonated oxime group leads to a great coordinative flexibility due to the well-known ability of the oximate group to bridge two or three metal ions. On the other hand, carboxylates are able to deprotonate the oxime group of 2-pyridyloximes under mild conditions (the use of external hydroxides often perplexes the reactions). Besides their deprotonating ability, the $\mathrm{R}^{\prime} \mathrm{CO}_{2}{ }^{-}$ions are flexible ligands, a consequence of their ability to adopt a number of different ligation modes, both terminal and bridging as well as both bidentate and tridentate. The additional inorganic monoanions in the ternary "ligand blends" often behave as terminal ligands and help the formation of clusters (and not coordination polymers). However, sometimes they act as bridging ligands, and this may eventually lead to clusters with complicated structures; the formation of coordination polymers cannot be ruled out in such a case. Thus, a variety of $\mathrm{Cr}, \mathrm{Mn}, \mathrm{Fe}, \mathrm{Co}, \mathrm{Ni}$, and $\mathrm{Cu}$ clusters [22-39] with nuclearities ranging from 3 to 12 have been characterized from our [23-36] and other [21,37-39] groups, some of them possessing interesting magnetic properties, including single-molecule magnetism behaviour [33, 40].

Recently, we have begun a program which can be considered as a modification of the above-mentioned binary "ligand blend" approach. We have been exploring the use of other inorganic ions, such as $\mathrm{SO}_{4}{ }^{2-}$, instead of the carboxylato ligand, $\mathrm{R}^{\prime} \mathrm{CO}_{2}{ }^{-}$, in the $3 \mathrm{~d}$-metal cluster 
<smiles>[R]/C(=N/O)c1ccccn1</smiles>

$$
\begin{aligned}
& \mathrm{R}=\mathrm{H} ;(\text { py }) \mathrm{C}(\mathrm{H}) \mathrm{NOH} \\
& \mathrm{R}=\mathrm{Me} ;(\mathrm{py}) \mathrm{C}(\mathrm{Me}) \mathrm{NOH} \\
& \mathrm{R}=\mathrm{Ph} ;(\mathrm{py}) \mathrm{C}(\mathrm{Ph}) \mathrm{NOH}
\end{aligned}
$$

Scheme 1: General structural formula and abbreviations of simple 2-pyridyl oximes.

chemistry with 2-pyridyloximate ligands. The sulfate ion [41] is a ligand with great coordinative flexibility $\left(\mu_{2}, \mu_{3}\right.$, $\mu_{4}, \mu_{5}, \mu_{6}, \mu_{8}$, or $\mu_{10}$ potential), see Scheme 2 . Metal-sulfato complexes have been studied for their roles in the field of porous framework materials [42, 43], in catalysis [44], in the construction of luminescent molecular materials $[45,46]$, and in medicinal [47], environmental [48], and bioinorganic [49] chemistry. The possible advantages of using $\mathrm{SO}_{4}{ }^{2-}$ instead of $\mathrm{R}^{\prime} \mathrm{CO}_{2}{ }^{-}$include (i) the possibility of triggering aggregation of preformed smaller cationic species into new, higher-nuclearity products and (ii) the possible diversion of known reaction systems developed using monoanionic carboxylates to new species as a result of the higher charge and higher denticity/bridging capability of sulfates. Thus, the initial employment of the sulfate ion in $\mathrm{Ni}^{\mathrm{II}} /($ py $) \mathrm{C}(\mathrm{R}) \mathrm{NOH}$ ( $\mathrm{R}=\mathrm{Me}, \mathrm{Ph}, \mathrm{NH}_{2}$ ) chemistry has led to the isolation and characterization of high-nuclearity $\mathrm{Ni}^{\mathrm{II}}$ compounds, such as $\mathrm{Ni}_{12}[50]$ and $\mathrm{Ni}_{6}[51,52]$ clusters which possess interesting structural properties.

In this work, we expand our efforts to a different member of 2-pyridyl oximes which is di-2-pyridyl ketone oxime, (py $)_{2} \mathrm{CNOH}$, and report the synthesis and characterization of the new tetranuclear compound $\left[\mathrm{Ni}_{4}\left\{(\mathrm{py})_{2} \mathrm{CNO}\right\}_{4}\left(\mathrm{SO}_{4}\right)_{2}(\mathrm{MeOH})_{4}\right]$. The structure of the compound has been determined by single-crystal X-ray diffraction. The IR data are discussed in terms of the nature of bonding and the structure of the complex.

\section{Experimental}

2.1. General and Physical Measurements. All manipulations were performed under aerobic conditions using materials (reagent grade) and solvents as received.

Microanalyses ( $\mathrm{C}, \mathrm{H}, \mathrm{N}$ ) were performed by the University of Ioannina (Greece) Microanalytical Laboratory using an EA 1108 Carlo Erba analyzer. IR spectra $\left(4000-400 \mathrm{~cm}^{-1}\right)$ were recorded on a Perkin-Elmer 16 PC FT-spectrometer with samples prepared as $\mathrm{KBr}$ pellets.

\subsection{Compound Preparation}

2.2.1. $\left[\mathrm{Ni}_{4}\left\{(p y)_{2} \mathrm{CNO}_{4}\left(\mathrm{SO}_{4}\right)_{2}(\mathrm{MeOH})_{4}\right]\right.$ (1). $\mathrm{NEt}_{3}(0.139$ $\mathrm{ml}, 1.00 \mathrm{mmol}$ ) was added to a colourless solution of (py) ${ }_{2} \mathrm{CNOH}(0.199 \mathrm{~g}, 1.00 \mathrm{mmol})$ in $\mathrm{MeOH}(25 \mathrm{ml})$. Subsequently, solid $\mathrm{NiSO}_{4} \cdot 6 \mathrm{H}_{2} \mathrm{O}(0.263 \mathrm{~g}, 1.00 \mathrm{mmol})$ was added, and the resulting red solution was stirred for $1 \mathrm{~h}$ at room

\begin{tabular}{|c|c|}
\hline Complex & 1 \\
\hline Empirical formula & $\mathrm{Ni}_{4} \mathrm{C}_{48} \mathrm{H}_{48} \mathrm{~N}_{24} \mathrm{O}_{16} \mathrm{~S}_{2}$ \\
\hline Formula weight & 1515.97 \\
\hline Colour, habit & orange, rod \\
\hline Crystal system & orthorhombic \\
\hline Space group & $P_{c c n}$ \\
\hline$a(\AA)$ & $14.2969(10)$ \\
\hline$b(\AA)$ & $20.9678(14)$ \\
\hline$c(\AA)$ & $18.5395(13)$ \\
\hline$V\left(\AA^{3}\right)$ & $5557.7(7)$ \\
\hline$Z$ & 4 \\
\hline$\rho_{\text {calc }}\left(\mathrm{g} \mathrm{cm}^{-3}\right)$ & 1.609 \\
\hline Radiation, $\lambda(\AA)$ & 0.71073 \\
\hline$\mu\left(\mathrm{mm}^{-1}\right)$ & 1.488 \\
\hline$F(000)$ & 2760 \\
\hline Temperature (K) & $100(2)$ \\
\hline $2 \theta_{\max }\left[{ }^{\circ}\right]$ & 61 \\
\hline Ranges $h$ & $-18 \rightarrow 18$ \\
\hline$k$ & $-21 \rightarrow 27$ \\
\hline$l$ & $-27 \rightarrow 23$ \\
\hline Measured reflections & 42848 \\
\hline Unique reflections & 6377 \\
\hline Reflections used & 3703 \\
\hline \multicolumn{2}{|l|}{$(I>2 \sigma(I))$} \\
\hline Parameters refined & 374 \\
\hline $\mathrm{GoF}\left(\mathrm{on} F^{2}\right)$ & 0.903 \\
\hline$R_{1}^{\mathrm{a}}(I>2 \sigma(I))$ & 0.0464 \\
\hline$w R_{2}{ }^{\mathrm{b}}(I>2 \sigma(I))$ & 0.1042 \\
\hline$(\Delta \rho)_{\max } /(\Delta \rho)_{\min }\left(\mathrm{e} \AA^{-3}\right)$ & $0.861 /-0.621$ \\
\hline
\end{tabular}
temperature. A small quantity of undissolved material was
TABle 1: Summary of crystal data, data collection, and structure refinement for the X-ray diffraction study of complex 1 .

removed by filtration and the dark red filtrate layered with $\mathrm{Et}_{2} \mathrm{O}(50 \mathrm{ml})$. Slow mixing gave X-ray quality, orange crystals which were collected by filtration, washed with $\mathrm{Et}_{2} \mathrm{O}(2 \times 3 \mathrm{ml})$, and dried in air; yield $57 \%$. The dried solid was analyzed satisfactorily as $\mathbf{1} \cdot \mathrm{MeOH}$. Anal. Calc. for $\mathrm{C}_{49} \mathrm{H}_{52} \mathrm{Ni}_{4} \mathrm{~N}_{24} \mathrm{O}_{17} \mathrm{~S}_{2}$ : C, 38.02; H, 3.99; N, 21.72. Found: C, 38.45; H, 3.87; N, 21.37\%. IR ( $\mathrm{KBr}$ pellet): $\widetilde{v}=3388 \mathrm{sb}$, $2902 \mathrm{w}, 1654 \mathrm{w}, 1598 \mathrm{~m}, 1460 \mathrm{~m}, 1430 \mathrm{~m}, 1376 \mathrm{w}, 1340 \mathrm{w}$, $1282 \mathrm{w}, 1219 \mathrm{~m}, 1130 \mathrm{~m}, 1118 \mathrm{~s}, 1086 \mathrm{~s}, 1045 \mathrm{~s}, 1020 \mathrm{~m}$, $982 \mathrm{~m}, 896 \mathrm{w}, 788 \mathrm{w}, 748 \mathrm{~m}, 702 \mathrm{~m}, 670 \mathrm{~m}, 641 \mathrm{~m}, 618 \mathrm{~s}$, $591 \mathrm{w}, 452 \mathrm{w} \mathrm{cm}^{-1}$.

2.3. Single-Crystal X-Ray Crystallography. A crystal of 1 with appropriate dimensions $0.08 \times 0.03 \times 0.01 \mathrm{~mm}$ was attached to a glass fiber using silicone grease. Data were collected on an Oxford Diffraction Xcalibur-3 diffractometer, equipped with a Sapphire CCD area detector, at $100 \mathrm{~K}$, using a graphite monochromated Mo $\mathrm{K} \alpha$ radiation. Complete crystal data and parameters for data collection and processing are listed in Table 1. 
<smiles>[M]O[Sb](O)(O)O</smiles>

1.1000<smiles>[M]O[Sb]1(O[M])O[M]O1</smiles>

2.1111<smiles>[M]O[Sb](O)(O)O[M]</smiles>

1.1100<smiles>[M]O[Sb]1([O])OCO1</smiles>

2.2110<smiles>[M]O[Sn](O)(O)O[M]</smiles>

2.1100<smiles>[M]O[Sb](O)(O[M])O[M]</smiles>

2.1110<smiles>[M]O[Sb](O[M])(O[M])O[M]</smiles>

4.1111<smiles>[M]OS(O)(O[M])O[M]</smiles>

3.1110<smiles>[M]O[Sb](O)(O)O[M]</smiles>

3.2100<smiles>[M]OS(O[M])(O[M])O[M]</smiles>

3.2111<smiles>[M]OS(O)(O[M])O[M]</smiles>

4.2200<smiles>[M]OS(O[M])(O[M])O[M]</smiles>

5.2211<smiles>[M]O[Si](O[M])(O[M])O[M]</smiles>

8.2222<smiles>[M]O[Si](O[M])(O[M])S([M])(O[M])O[M]</smiles>

10.3322<smiles>[M]O[Sb](O)(O[M])O[M]</smiles>

4.2210

6.2211

Scheme 2: The up to now crystallographically established coordination modes of the sulfato ligand and the Harris notation [53] which describes these modes.

The structure was solved by direct methods using SIR92 [54] and refined by full-matrix least-squares techniques on $F^{2}$ with SHELXL-97 [55]. Some residual electron density in the accessible voids of the structure was too disordered to refine as solvent molecules; therefore, the SQUEEZE procedure [56] of PLATON was employed to remove the contribution of the electron density in the solvent region from the intensity data. The solvent-free model and intensity data were used for the final results reported here. The non$\mathrm{H}$ atoms were treated anisotropically. The $\mathrm{H}$ atoms of the (py) ${ }_{2} \mathrm{CNOH}$ ligands and the methyl groups of the methanol molecules were placed in calculated, ideal positions and 


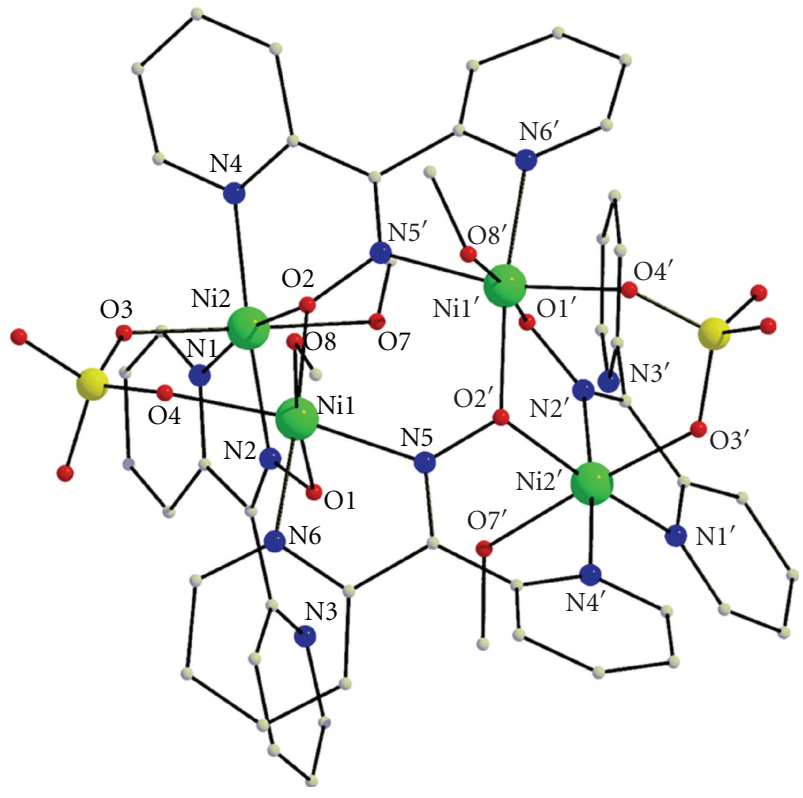

FIGURE 1: The molecular structure of $\mathbf{1} . \mathrm{H}$ atoms have been omitted for clarity.

refined as riding on their respective $\mathrm{C}$ atoms. The $\mathrm{H}$ atom of the $\mathrm{OH}$ group of one independent methanol molecule $(\mathrm{O}(8) \mathrm{H})$ was located in difference Fourier maps and was refined isotropically, but the $\mathrm{H}$ atom of the $\mathrm{OH}$ group of the second independent methanol molecule $(\mathrm{O}(7) \mathrm{H})$ could not be located. The programs used were CRYSALIS CCD [57] for data collection, CRYSALIS RED [57] for cell and data refinement, WINGX [58] for crystallographic calculations, and MERCURY [59] and DIAMOND [60] for molecular graphics.

\section{Results and Discussion}

3.1. Synthetic Comments. Our general synthetic approach for the isolation of $\mathrm{Ni}^{\mathrm{II}} / 2$-pyridyloximate/sulfato clusters has been to treat the metal sulfate "salt" with the appropriate ligand and a base in a variety of solvents. The addition of base is necessary for the deprotonation of the oxime ligand.

Treatment of $\mathrm{NiSO}_{4} \cdot 6 \mathrm{H}_{2} \mathrm{O}$ with one equivalent of (py) ${ }_{2} \mathrm{CNOH}$ and one equivalent of $\mathrm{NEt}_{3}$ in $\mathrm{MeOH}$ gave a red solution which, upon crystallization, gave orange crystals of the new tetranuclear cluster which can be written as $\left[\mathrm{Ni}_{4}\left\{(\mathrm{py})_{2} \mathrm{CNO}\right\}_{4}\left(\mathrm{SO}_{4}\right)_{2}(\mathrm{MeOH})_{4}\right](\mathbf{1})$. Its formation can be summarized in (1)

$$
\begin{aligned}
& 4 \mathrm{NiSO}_{4} \cdot 6 \mathrm{H}_{2} \mathrm{O}+4(\mathrm{py})_{2} \mathrm{CNOH}+4 \mathrm{NEt}_{3}+4 \mathrm{MeOH} \\
& \stackrel{\mathrm{MeOH}}{\longrightarrow}\left[\mathrm{Ni}_{4}\left\{(\mathrm{py})_{2} \mathrm{CNO}\right\}_{4}\left(\mathrm{SO}_{4}\right)_{2}(\mathrm{MeOH})_{4}\right] \\
& +2\left(\mathrm{HNEt}_{3}\right)_{2} \mathrm{SO}_{4}+24 \mathrm{H}_{2} \mathrm{O} .
\end{aligned}
$$

As expected, the nature of the base is not crucial for the identity of the product, and it affects only its crystallinity, and in some cases its purity; we were able to isolate $\mathbf{1}$ by using a plethora of different bases such as $\mathrm{NaOMe}, \mathrm{NMe}_{4} \mathrm{OH}$,

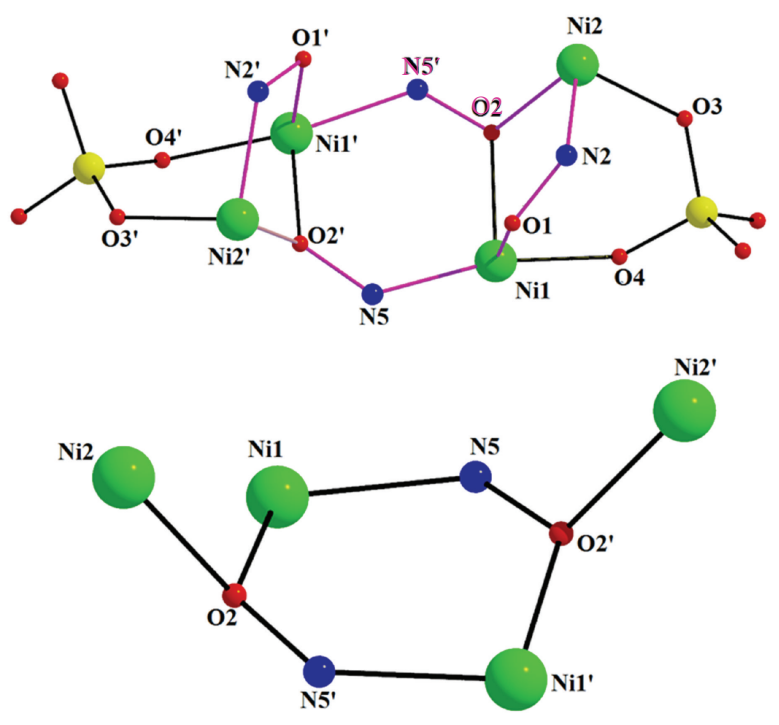

FIGURE 2: Top: the $\left[\mathrm{Ni}_{4}\left(\mu-\mathrm{SO}_{4}\right)_{2}\left(\mu_{2}-\mathrm{ONR}\right)_{2}\left(\mu_{3}-\mathrm{ONR}\right)_{2}\right]$ core of complex 1 , where $\mathrm{R}-=-\mathrm{C}(\mathrm{py})_{2}$. The metallacrown-type ring is highlighted. Bottom: the core of $\mathbf{1}$ using only the $\mu_{3}$ oximate groups.

$\mathrm{NEt}_{4} \mathrm{OH}$, and $\mathrm{LiOH} \cdot \mathrm{H}_{2} \mathrm{O}$. Small changes in the molar ratio of the reactants, the crystallization method, and the presence of counterions do not seem to affect the identity of the isolated product.

3.2. Description of Structure. Partially labeled plots of the complete structure and the core of the molecule $\left[\mathrm{Ni}_{4}\left\{(\mathrm{py})_{2} \mathrm{CNO}\right\}_{4}\left(\mathrm{SO}_{4}\right)_{2}(\mathrm{MeOH})_{4}\right]$ that is present in complex 1 are shown in Figures 1 and 2, respectively. Selected interatomic distances and angles are listed in Table 2.

The structure of 1 consists of tetranuclear molecules $\left[\mathrm{Ni}_{4}\left\{(\mathrm{py})_{2} \mathrm{CNO}_{4}\left(\mathrm{SO}_{4}\right)_{2}(\mathrm{MeOH})_{4}\right]\right.$ which lie on a crystallographic inversion center. The metal ions are held together by two 3.2111 and two 2.1110 (using Harris notation, [53], Scheme 3) (py) ${ }_{2} \mathrm{CNO}^{-}$ligands, as well as two $2.1100 \mathrm{SO}_{4}{ }^{2-}$ ions. Four $\mathrm{MeOH}$ molecules act as terminal ligands and complete the coordination sphere of the four metal centers. The molecule has a metallacrown-type topology [61]. A pseudo 12-MC-4 ring forms; the true 12-MC-4 topology is "destroyed" by the bridging character of the oximate oxygen atoms $\mathrm{O} 2$ and $\mathrm{O} 2$ '.

A distorted octahedral environment is created about each metal center; the chromophores are represented by the following formulas $\mathrm{Ni}\left(1,1^{\prime}\right)\left(\mathrm{N}_{\mathrm{py}}\right)\left(\mathrm{N}_{\mathrm{ox}}\right)\left(\mathrm{O}_{\mathrm{ox}}\right)_{2}\left(\mathrm{O}_{\text {sulf }}\right)\left(\mathrm{O}_{\text {met }}\right)$ and $\mathrm{Ni}\left(2,2^{\prime}\right)\left(\mathrm{N}_{\text {py }}\right)_{2}\left(\mathrm{~N}_{\mathrm{ox}}\right)\left(\mathrm{O}_{\mathrm{ox}}\right)\left(\mathrm{O}_{\text {sulf }}\right)\left(\mathrm{O}_{\text {met }}\right)$, where the abbreviations "py", "ox", "sulf," and "met" are for the 2-pyridyl, oximate, sulfato, and methanolic donor atoms, respectively. The average $\mathrm{Ni}-\mathrm{O}_{\mathrm{ox}}, \mathrm{Ni}-\mathrm{N}_{\mathrm{ox}}$, and $\mathrm{Ni}-\mathrm{N}_{\mathrm{py}}$ bond lengths of 2.054(3), 2.043(3), and 2.071(3) $\AA$, respectively, agree well with the values expected for high-spin $\mathrm{Ni}^{\mathrm{II}}$ ions in octahedral environment $[34,35,62-64]$. The $\mathrm{Ni}-\mathrm{O}_{\text {sulf }}$ bond lengths are typical $[41,51,62,65]$. The fact that $\mathrm{S}-(\mathrm{O} 3, \mathrm{O} 4)$ (average $1.474 \AA$ ) > S- $(\mathrm{O} 5, \mathrm{O} 6)$ (average $1.450 \AA$ ) reflects the coordinating nature of $\mathrm{O} 3$ and $\mathrm{O} 4$ and the noncoordinating 
TABLE 2: Selected interatomic distances $(\AA)$ and angles ( $($ ) for $\mathbf{1}$.

\begin{tabular}{lccc}
\hline Ni1-O1 & $2.046(3)$ & Ni2-O2 & $2.071(3)$ \\
Ni1-O2 & $2.046(3)$ & Ni2-O3 & $2.042(3)$ \\
Ni1-O4 & $2.033(3)$ & Ni2-O7 & $2.163(3)$ \\
Ni1-O8 & $2.048(3)$ & Ni2-N1 & $2.090(3)$ \\
Ni1-N5 & $2.090(3)$ & Ni2-N2 & $1.997(4)$ \\
Ni1-N6 & $2.074(3)$ & Ni2-N4 & $2.053(3)$ \\
\hline O1-Ni1-O2 & $89.59(11)$ & O2-Ni2-O3 & $94.82(11)$ \\
O1-Ni1-O4 & $101.65(11)$ & O2-Ni2-O7 & $88.69(10)$ \\
O1-Ni1-O8 & $173.53(11)$ & O2-Ni2-N1 & $169.13(12)$ \\
O1-Ni1-N5 & $82.89(11)$ & O2-Ni2-N2 & $90.44(12)$ \\
O1-Ni1-N6 & $83.38(12)$ & O2-Ni2-N4 & $84.07(12)$ \\
O2-Ni1-O4 & $84.24(11)$ & O3-Ni2-O7 & $176.29(10)$ \\
O2-Ni1-O8 & $88.62(11)$ & O3-Ni2-N1 & $88.91(12)$ \\
O2-Ni1-N5 & $107.12(11)$ & O3-Ni2-N2 & $95.11(12)$ \\
O2-Ni1-N6 & $170.67(12)$ & O3-Ni2-N4 & $87.08(12)$ \\
O4-Ni1-O8 & $84.36(12)$ & O7-Ni2-N1 & $87.86(11)$ \\
O4-Ni1-N5 & $167.92(13)$ & O7-Ni2-N2 & $86.05(12)$ \\
O4-Ni1-N6 & $91.16(12)$ & O7-Ni2-N4 & $92.09(12)$ \\
O8-Ni1-N5 & $91.70(12)$ & N1-Ni2-N2 & $79.04(13)$ \\
O8-Ni1-N6 & $99.02(12)$ & N1-Ni2-N4 & $106.36(13)$ \\
N5-Ni1-N6 & $78.16(13)$ & N2-Ni2-N4 & $174.25(13)$ \\
\hline
\end{tabular}

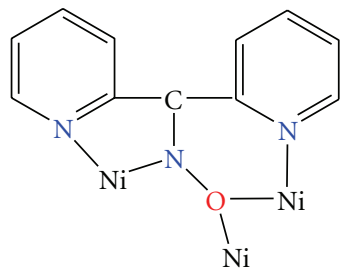

3.2111

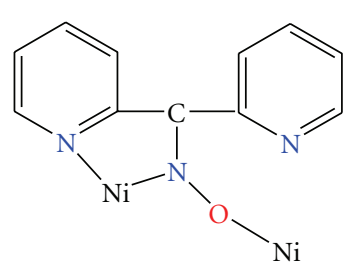

2.1110
Scheme 3: The two different coordination modes of the (py $)_{2} \mathrm{CNO}^{-}$ ligands present in complex 1 and the Harris notation [53] which describes them.

character of $\mathrm{O} 5$ and $\mathrm{O} 6$; as expected, the sulfur to "free" oxygen bond lengths are the shortest.

The crystal structure of $\mathbf{1}$ is stabilized by strong interand intramolecular hydrogen bonds. The intramolecular hydrogen bonds involve the $\mathrm{O}$ atom $(\mathrm{O} 7$ and its symmetry equivalent) belonging to a methanol ligand as donor and the $\mathrm{O}$ atom ( $\mathrm{O} 1$ and its symmetry equivalent) of the doubly bridging organic ligand as acceptor $[\mathrm{O} 1 \cdots \mathrm{O} 7=$ $2.721(3) \AA]$. The $\mathrm{O}$ atom of the remaining methanol ligand (O8 and its symmetry equivalent) is participating as donor in an intermolecular hydrogen bond with the acceptor being the pyridyl $\mathrm{N}$ atom (N3 and its symmetry equivalent) of the doubly bridging organic ligand [O $\cdots \mathrm{N} 3=2.851(3) \AA$, $\mathrm{H}(\mathrm{O} 8) \cdots \mathrm{N} 3=1.987(3) \AA$, and $\mathrm{O} 8-\mathrm{H}(\mathrm{O} 8)-\mathrm{N} 3=172.1(1)]$. This hydrogen bonding leads to the formation of a 1D chain along the $c$ axis (Figure 3).

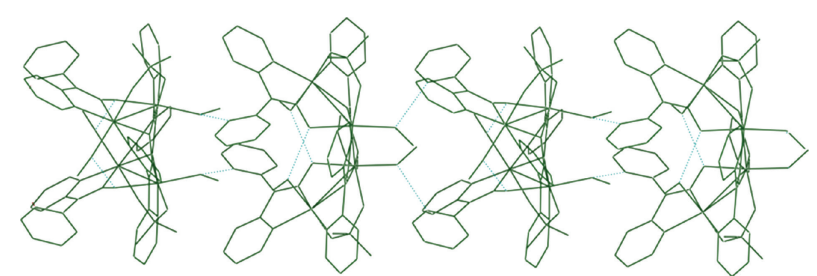

FIGURE 3: Representation of a part of the 1D chain formed in $\mathbf{1}$ along the $c$ axis. The dotted lines represent $\mathrm{H}$ bonds.

The molecule of 1 contains the $\left[\mathrm{Ni}_{4}\left(\mu-\mathrm{SO}_{4}\right)_{2}\left(\mu_{2}\right.\right.$ $\left.\mathrm{ONR})_{2}\left(\mu_{3}-\mathrm{ONR}\right)_{2}\right]$ core, where R- $=-\mathrm{C}(\mathrm{py})_{2}$ (Figure 2 , top $)$. An alternative description of the core (using only the $\mu_{3}$ oximate groups) is $\left[\mathrm{Ni}_{4}\left(\mu_{3}-\mathrm{ONR}\right)_{2}\right]^{6+}$ (Figure 2 , bottom). The topology of the four $\mathrm{Ni}^{\mathrm{II}}$ ions can be also described as "saddle-like," and it is observed for the first time in $\mathrm{Ni}_{4}$ clusters. The most common topologies of the metal ions in $\mathrm{Ni}_{4}^{\mathrm{II}}$ complexes are the cubanes [66-73] and the face-shared distorted dicubanes in which one of the corners of each cubane is missing [74-79], while there are few $\mathrm{Ni}_{4}$ clusters in which the metal ions adopt less common topologies such as linear [80-82], rectangular [83-87], and chair-like [88, 89] as follows.

Complex 1 joins a small but growing family of structurally characterized $\mathrm{Ni}(\mathrm{II})$ complexes containing the neutral or anionic forms of di-2-pyridyl ketone oxime as ligands $[34,36,88-92]$. The special features of 1 compared to the other members of this family are (1) It is the first example of these species containing the sulfato ligand, and (2) it has a unique $\mathrm{Ni}_{4}$ clusters "saddle-like" metal topology.

3.3. IR Spectra. The medium intensity bands at 1568 and $1094 \mathrm{~cm}^{-1}$ in the spectrum of the free ligand (py) ${ }_{2} \mathrm{CNOH}$ are assigned to $v(\mathrm{C}=\mathrm{N})_{\text {oxime }}$ and $v(\mathrm{~N}-\mathrm{O})_{\text {oxime }}$ modes, respectively $[51,52,93]$. The $1094 \mathrm{~cm}^{-1}$ band is shifted to a higher wavenumber $\left(1118 \mathrm{~cm}^{-1}\right)$ in 1 . This shift is in accord with the concept that upon deprotonation and oximate$\mathrm{O}$ coordination, there is a higher contribution of $\mathrm{N}=\mathrm{O}$ to the electronic structure of the oximate group; consequently, the $v(\mathrm{~N}-\mathrm{O})$ vibration shifts to a higher wavenumber in the complex relative to $(\mathrm{py})_{2} \mathrm{CNOH}$ [36]. Somewhat to our surprise, the $1568 \mathrm{~cm}^{-1}$ band is shifted to a higher wavenumber in the complex $\left(1598 \mathrm{~cm}^{-1}\right)$, overlapping with an aromatic stretch. This shift may be indicative of the oxime nitrogen coordination [94]. Extensive studies on Schiff base complexes (which also contain a $\mathrm{C}=\mathrm{N}$ bond) have shown [95] that a change in the s character of the nitrogen lone pair occurs upon coordination such that the s character of nitrogen orbital involved in the $\mathrm{C}=\mathrm{N}$ bond increases; this change in hybridization produces a greater $\mathrm{C}=\mathrm{N}$ stretching force constant relative to the free neutral ligand.

The in-plane deformation band of the 2-pyridyl ring of free (py) ${ }_{2} \mathrm{CNOH}$ at $622 \mathrm{~cm}^{-1}$ shifts upwards $\left(641 \mathrm{~cm}^{-1}\right)$, confirming the involvement of the ring- $\mathrm{N}$ atom in coordination [96]. The presence of the $618 \mathrm{~cm}^{-1}$ bond in the spectrum of $\mathbf{1}$ indicates that some 2-pyridyl rings are "free," that is, 
uncoordinated, in accordance with the $2.1110(\mathrm{py})_{2} \mathrm{CNO}^{-}$ ligands that are present in the complex.

The IR spectrum of the free, that is, ionic, sulfate (the ion belongs to the $T_{d}$ point group) consists of two bands at $\sim 1105$ and $\sim 615 \mathrm{~cm}^{-1}$, assigned to the $v_{3}\left(F_{2}\right)$ stretching $\left[v_{d}(\mathrm{SO})\right]$ and $v_{4}\left(F_{2}\right)$ bending $\left[\delta_{d}(\mathrm{OSO})\right]$ modes, respectively $[41,97]$. The $v_{1}\left(A_{1}\right)$ stretching $\left[v_{s}(\mathrm{SO})\right]$ and $v_{2}(E)$ bending $\left[\delta_{d}(\mathrm{OSO})\right]$ fundamentals are not IR active. The coordination of $\mathrm{SO}_{4}{ }^{2-}$ to metal ions decreases the symmetry of the group, and the $v_{3}$ and $v_{4}$ modes are split $[41,97]$. In the case when the $\mathrm{SO}_{4}{ }^{2-}$-site symmetry is lowered from $T_{d}$ to $C_{2 v}$ (bidentate chelating or bridging coordination), which is the case in 1 , both $v_{1}$ and $v_{2}$ appear in the IR spectrum, while $v_{3}$ and $v_{4}$ each splits into three IR-active vibrations [97]. Thus, the bands at 1219,1130 , and $1020 \mathrm{~cm}^{-1}$ are attributed to the $v_{3}$ modes [97], while the bands at 591, 618, and $670 \mathrm{~cm}^{-1}$ are assigned to the $v_{4}$ modes $[13,74-79]$ with the intermediate wavenumber band being superimposed by a ligand's vibration. The band at $982 \mathrm{~cm}^{-1}$ and the weak feature at $452 \mathrm{~cm}^{-1}$ can be assigned $[41,97]$ to the $v_{1}$ and $v_{2}$ modes, respectively. These spectral features agree with the low $C_{2 v}$ symmetry for the sulfato ligand in the complex, as also confirmed crystallographically.

\section{Conclusions}

The present work extends the body of results that emphasize the ability of the sulfate ion to create unique structural types in 3d-metal cluster chemistry. The study of the coordination chemistry of the binary $\mathrm{SO}_{4}{ }^{2-} /(\mathrm{py})_{2} \mathrm{CNOH}$ ligand system in the presence of base in $\mathrm{MeOH}$ has provided access to the novel tetranuclear $\mathrm{Ni}(\mathrm{II})$ cluster $\left[\mathrm{Ni}_{4}\left\{(\mathrm{py})_{2} \mathrm{CNO}\right\}_{4}\left(\mathrm{SO}_{4}\right)_{2}(\mathrm{MeOH})_{4}\right]$ (1). Complex $\mathbf{1}$ contains the $\left[\mathrm{Ni}_{4}\left(\mu-\mathrm{SO}_{4}\right)_{2}\left(\mu_{2}-\mathrm{ONR}\right)_{2}\left(\mu_{3}-\mathrm{ONR}\right)_{2}\right]$ core, where R- = $\mathrm{C}(\mathrm{py})_{2}$, with a unique saddle-like topology of the $\mathrm{Ni}^{\mathrm{II}}$ ions; it is thus a valuable addition to the family of tetranuclear $\mathrm{Ni}^{\mathrm{II}}$ clusters.

Analogues of 1 with 2-pyridinealdoxime [(py) $\mathrm{C}(\mathrm{H}) \mathrm{NOH}$, methyl(2-pyridyl)ketone oxime $[(\mathrm{py}) \mathrm{C}(\mathrm{Me}) \mathrm{NOH}]$, or phenyl(2-pyridyl)ketone oxime [(py)C(ph)NOH] (Scheme 1 ) are not known, until to date, and further research efforts are in progress to determine the appropriate reaction conditions that could possibly favor such species. It is likely that the preparation and stability of such tetranuclear complexes are dependent on the particular nature of the $\mathrm{R}$ substituent on the oximate carbon. We are currently working on the chemistry of the $\mathrm{NiSO}_{4} \cdot 6 \mathrm{H}_{2} \mathrm{O} /(\mathrm{py}) \mathrm{C}(\mathrm{R}) \mathrm{NOH}(\mathrm{R}=\mathrm{H}$, $\mathrm{Me}, \mathrm{Ph}$ ) reaction systems.

\section{Supporting Information}

CCDC 802606 contains the supplementary crystallographic data for 1 . These data can be obtained free of charge via http://www.ccdc.cam.ac.uk/conts/retrieving.html or from the Cambridge Crystallographic Data Centre, 12 Union Road, Cambridge CB2 1EZ, UK; fax: $(+44) 1223-336033$ or e-mail: deposit@ccdc.cam.ac.uk.

\section{References}

[1] V. Yu. Kukushkin and A. J. L. Pombeiro, "Oxime and oximate metal complexes: unconventional synthesis and reactivity," Coordination Chemistry Reviews, vol. 181, no. 1, pp. 147-175, 1999.

[2] A. G. Smith, P. A. Tasker, and D. J. White, "The structures of phenolic oximes and their complexes," Coordination Chemistry Reviews, vol. 241, no. 1-2, pp. 61-85, 2003.

[3] M. G. Davidson, A. L. Johnson, M. D. Jones, M. D. Lunn, and M. F. Mahon, "Titanium(IV) complexes of oximes-novel binding modes," Polyhedron, vol. 26, no. 5, pp. 975-980, 2007.

[4] D. Mandal, V. Bertolasi, G. Aromí, and D. Ray, "A ketone oximate based cyclic cationic [Ni] inverse metallacrown from simultaneous chelation and bridging of two ligands," Dalton Transactions, no. 20, pp. 1989-1992, 2007.

[5] C. P. Raptopoulou, A. K. Boudalis, Y. Sanakis et al., "Hexanuclear iron(III) salicylaldoximato complexes presenting the $\left[\mathrm{Fe}_{6}\left(\mu_{3}-\mathrm{O}\right)_{2}\left(\mu_{2}-\mathrm{O}\right)_{2}\right]^{12+}$ core: syntheses, crystal structures, and spectroscopic and magnetic characterization," Inorganic Chemistry, vol. 45, no. 5, pp. 2317-2326, 2006.

[6] V. V. Pavlishchuk, S. V. Kolotilov, A. W. Addison et al., "Structural, magnetic and related attributes of some oximatebridged tetranuclear nickel(II) rhombs and a dinuclear congener," Dalton Transactions, no. 8, pp. 1587-1595, 2003.

[7] D. T. Rosa, J. A. Krause Baue, and M. J. Baldwin, "Structural and spectroscopic studies of the versatile coordination chemistry of the chiral ligand N,N-bis(1-propan-2-onyl oxime)L-methionine $\mathrm{N}$ '-methylamide with $\mathrm{Ni}$ and $\mathrm{Zn}$," Inorganic Chemistry, vol. 40, no. 7, pp. 1606-1613, 2001.

[8] M. J. Goldcamp, S. E. Robison, J. A. Krause Bauer, and M. J. Baldwin, "Oxygen reactivity of a Nickel(II)-polyoximate complex," Inorganic Chemistry, vol. 41, no. 9, pp. 2307-2309, 2002.

[9] M. N. Kopylovich, V. Yu. Kukushkin, M. Haukka, J. J. R. Fraústo da Silva, and A. J. L. Pombeiro, "Zinc(II)/ketoxime system as a simple and efficient catalyst for hydrolysis of organonitriles," Inorganic Chemistry, vol. 41, no. 18, pp. 47984804, 2002.

[10] S. Akine, T. Taniguchi, T. Saiki, and T. Nabeshima, "Ca- and Ba-selective receptors based on site-selective transmetalation of multinuclear polyoxime-zinc(II) complexes," Journal of the American Chemical Society, vol. 127, no. 2, pp. 540-541, 2005.

[11] A. J. L. Pombeiro and V. Yu. Kukushkin, "Reactions of coordinated nitriles," in Comprehensive Coordination Chemistry II, J. A. McClevery and T. C. Meyer, Eds., vol. 1, pp. 631-637, Elsevier, Amsterdam, The Netherlands, 2004.

[12] J. M. Thorpe, R. L. Beddoes, D. Collison et al., "Surface coordination chemistry: corrosion inhibition by tetranuclear cluster formation of iron with salicylaldoxime," Angewandte Chemie-International Edition, vol. 38, no. 8, pp. 1119-1121, 1999.

[13] J. Szymanowski, Hydroxyoximes and Copper Hydrometallurgy, CRC, London, UK, 1993.

[14] I. O. Fritsky, J. Swiatek-Kozlowska, A. Dobosz, T. Yu. Sliva, and N. M. Dudarenko, "Hydrogen bonded supramolecular structures of cationic and anionic module assemblies containing square-planar oximate complex anions," Inorganica Chimica Acta, vol. 357, no. 12, pp. 3746-3752, 2004.

[15] S. Khanra, T. Weyhermüller, E. Rentschler, and P. Chaudhuri, "Self-assembly of a nonanuclear nickel(II) complex and its magnetic properties," Inorganic Chemistry, vol. 44, no. 23, pp. 8176-8178, 2005. 
[16] C. J. Milios, C. P. Raptopoulou, A. Terzis et al., "Hexanuclear manganese(III) single-molecule magnets," Angewandte Chemie-International Edition, vol. 43, no. 2, pp. 210-212, 2003.

[17] J. P. Costes, F. Dahan, and A. Dupuis, "Is ferromagnetism an intrinsic property of the $\mathrm{Cu}^{\mathrm{II}} / \mathrm{Gd}^{\mathrm{III}}$ couple? 2 . Structures and magnetic properties of novel trinuclear complexes with $\mu$ phenolato- $\mu$-oximato $(\mathrm{Cu}-\mathrm{Ln}-\mathrm{Cu})$ cores $(\mathrm{Ln}=\mathrm{La}, \mathrm{Ce}, \mathrm{Gd}), "$ Inorganic Chemistry, vol. 39, no. 26, pp. 5994-6000, 2000.

[18] D. Robertson, J. F. Cannon, and N. Gerasimchuk, "Doublestranded metal-organic networks for one-dimensional mixed valence coordination polymers," Inorganic Chemistry, vol. 44, no. 23, pp. 8326-8342, 2005.

[19] C. J. Milios, A. Vinslava, W. Wernsdorfer et al., "Spin switching via targeted structural distortion," Journal of the American Chemical Society, vol. 129, no. 20, pp. 6547-6561, 2007.

[20] H. Miyasaka, R. Clérac, K. Mizushima et al., " $\left.\left[\mathrm{Mn}_{2} \text { (saltmen }\right)_{2} \mathrm{Ni}(\text { pao })_{2}(\mathrm{~L})_{2}\right](\mathrm{A})_{2}$ with $\mathrm{L}=$ Pyridine, 4picoline, 4-tert-butylpyridine, $\mathrm{N}$-methylimidazole and $\mathrm{A}=$ $\mathrm{ClO}_{4^{-}}, \mathrm{BF}_{4^{-}}, \mathrm{PF}_{6^{-}}, \mathrm{ReO}_{4^{-}}$: a family of single-chain magnets," Inorganic Chemistry, vol. 42, no. 25, pp. 8203-8213, 2003.

[21] P. Chaudhuri, "Homo- and hetero-polymetallic exchange coupled metal-oximates," Coordination Chemistry Reviews, vol. 243, no. 1-2, pp. 143-190, 2003.

[22] C. J. Milios, T. C. Stamatatos, and S. P. Perlepes, "The coordination chemistry of pyridyl oximes," Polyhedron, vol. 25, no. 1, pp. 134-194, 2006.

[23] C. J. Milios, E. Kefalloniti, C. P. Raptopoulou et al., "Octanuclearity and tetradecanuclearity in manganese chemistry: an octanuclear manganese(II)/(III) complex featuring the novel $\left[\mathrm{Mn}_{8}\left(\mu_{4}-\mathrm{O}\right)_{2}\left(\mu_{3}-\mathrm{OH}\right)_{2}\right]^{14+}$ core and $\left[\mathrm{Mn}_{10}^{\mathrm{II}} \mathrm{Mn}_{4}^{\mathrm{III}} \mathrm{O}_{4}\left(\mathrm{O}_{2} \mathrm{CMe}\right)_{20}\left\{(2-\mathrm{py})_{2} \mathrm{C}(\mathrm{OH}) \mathrm{O}\right\}_{4}\right](2-\mathrm{py}=2-$ pyridyl)," Chemical Communications, vol. 9, no. 7, pp. 819821, 2003.

[24] C. J. Milios, C. P. Raptopoulou, A. Terzis, R. Vicente, A. Escuer, and S. P. Perlepes, "Di-2-pyridyl ketone oxime in 3d-metal carboxylate cluster chemistry: a new family of mixed-valence MnMn complexes," Inorganic Chemistry Communications, vol. 6, no. 8, pp. 1056-1060, 2003.

[25] C. J. Milios, T. C. Stamatatos, P. Kyritsis et al., "Phenyl 2-pyridyl ketone and its oxime in manganese carboxylate chemistry: synthesis, characterisation, X-ray studies and magnetic properties of mononuclear, trinuclear and octanuclear complexes," European Journal of Inorganic Chemistry, no. 14, pp. 2885-2901, 2004.

[26] C. J. Milios, E. Kefalloniti, C. P. Raptopoulou et al., "2Pyridinealdoxime [(py)CHNOH] in manganese(II) carboxylate chemistry: mononuclear, dinuclear, tetranuclear and polymeric complexes, and partial transformation of (py) $\mathrm{CHNOH}$ to picolinate(-1)," Polyhedron, vol. 23, no. 1, pp. 83-95, 2004.

[27] M. Alexiou, E. Katsoulakou, C. Dendrinou-Samara et al., "Di-2-pyridyl ketone oxime in zinc chemistry: inverse 12metallacrown-4 complexes and cationic pentanuclear clusters," European Journal of Inorganic Chemistry, no. 10, pp. 1964-1978, 2005.

[28] T. C. Stamatatos, S. Dionyssopoulou, G. Efthymiou et al., "The first cobalt metallacrowns: preparation and characterization of mixed-valence cobalt(II/III), inverse 12-metallacrown-4 complexes," Inorganic Chemistry, vol. 44, no. 10, pp. 33743376, 2005.

[29] T. C. Stamatatos, A. K. Boudalis, Y. Sanakis, and C. P. Raptopoulou, "Reactivity and structural and physical studies of tetranuclear iron(III) clusters containing the $[\mathrm{Fe}(\mu-\mathrm{O})]$ "butterfly" core: an Fe cluster with an S = 1 ground state," Inorganic Chemistry, vol. 45, no. 18, pp. 7372-7381, 2006.

[30] T. C. Stamatatos, J. C. Vlahopoulou, Y. Sanakis et al., "Formation of the $\left\{\mathrm{Cu}_{3}^{\mathrm{II}}\left(\mu_{3}-\mathrm{OH}\right)\right\}^{5+}$ core in copper(II) carboxylate chemistry via use of di-2-pyridyl ketone oxime [(py) $\left.{ }_{2} \mathrm{CNOH}\right]$ : $\left[\mathrm{Cu}_{3}(\mathrm{OH})\left(\mathrm{O}_{2} \mathrm{CR}\right)_{2}\left\{(\mathrm{py})_{2} \mathrm{CNO}_{3}\right](\mathrm{R}=\mathrm{Me}, \mathrm{Ph})\right.$," Inorganic Chemistry Communications, vol. 9, no. 8, pp. 814-818, 2006.

[31] C. Papatriantafyllopoulou, C. P. Raptopoulou, A. Escuer, and C. J. Milios, "A rare all-Mn decametallic cage from distorted face-sharing cubes," Inorganica Chimica Acta, vol. 360, no. 1, pp. 61-68, 2007.

[32] K. V. Pringouri, C. P. Raptopoulou, A. Escuer, and T. C. Stamatatos, "Initial use of di-2-pyridyl ketone oxime in chromium carboxylate chemistry: triangular $\mathrm{Cr}(\mu-\mathrm{O})$ compounds and unexpected formation of a carboxylate-free dichromium(II,II) complex," Inorganica Chimica Acta, vol. 360, no. 1, pp. 69-83, 2007.

[33] T. C. Stamatatos, D. Foguet-Albiol, C. C. Stoumpos et al., "New Mn structural motifs in manganese single-molecule magnetism from the use of 2-pyridyloximate ligands," Polyhedron, vol. 26, no. 9-11, pp. 2165-2168, 2007.

[34] T. C. Stamatatos, E. Diamantopoulou, C. P. Raptopoulou, V. Psycharis, A. Escuer, and S. P. Perlepes, "Acetate/di-2pyridyl ketone oximate "blend" as a source of high-nuclearity nickel(II) clusters: dependence of the nuclearity on the nature of the inorganic anion present," Inorganic Chemistry, vol. 46, no. 7, pp. 2350-2352, 2007.

[35] T. C. Stamatatos, C. Papatriantafyllopoulou, E. Katsoulakou, C. P. Raptopoulou, and S. P. Perlepes, "2-Pyridyloximate clusters of cobalt and nickel," Polyhedron, vol. 26, no. 9-11, pp. 1830-1834, 2007.

[36] T. C. Stamatatos, A. Escuer, K. A. Abboud, C. P. Raptopoulou, S. P. Perlepes, and G. Christou, "Unusual structural types in nickel cluster chemistry from the use of pyridyl oximes: $\mathrm{Ni}$, $\mathrm{NiNa}$, and Ni clusters," Inorganic Chemistry, vol. 47, no. 24, pp. 11825-11838, 2008.

[37] M. Murugesu, K. A. Abboud, and G. Christou, "New hexanuclear and dodecanuclear Fe(III) clusters with carboxylate and alkoxide-based ligands from cluster aggregation reactions," Polyhedron, vol. 23, no. 17, pp. 2779-2788, 2004.

[38] T. Afrati, C. Dendrinou-Samara, C. P. Raptopoulou, A. Terzis, V. Tangoulis, and D. P. Kessissoglou, "A tetranuclear mixedvalent MnMn compound with a $(\mu-\mathrm{O}) \mathrm{Mn}$ core," Angewandte Chemie-International Edition, vol. 41, no. 12, pp. 2148-2150, 2002.

[39] A. J. Stemmler, J. W. Kampf, and V. L. Pecoraro, "Synthesis and crystal structure of the first inverse 12-metallacrown-4," Inorganic Chemistry, vol. 34, no. 9, pp. 2271-2272, 1995.

[40] T. C. Stamatatos, D. Foguet-Albiol, C. C. Stoumpos et al., "Initial example of a triangular single-molecule magnet from ligand-induced structural distortion of a $[\mathrm{MnO}]$ complex," Journal of the American Chemical Society, vol. 127, no. 44, pp. 15380-15381, 2005.

[41] C. Papatriantafyllopoulou, E. Manessi-Zoupa, A. Escuer, and S. P. Perlepes, "The sulfate ligand as a promising "player" in 3d-metal cluster chemistry," Inorganica Chimica Acta, vol. 362, no. 3, pp. 634-650, 2009.

[42] M. I. Khan, S. Cevik, and R. J. Doedens, "Inorganic-organic hybrids derived from oxovanadium sulfate motifs: synthesis and characterization of $\left[\mathrm{VO}(\mu-\mathrm{SO})\left(2,2^{\prime}\right.\right.$-bpy) $] \infty$," Chemical Communications, no. 19, pp. 1930-1931, 2001. 
[43] A. C. Sudik, A. R. Millward, N. W. Ockwig, A. P. Côté, J. Kim, and O. M. Yaghi, "Design, synthesis, structure, and gas $(\mathrm{N}, \mathrm{Ar}, \mathrm{CO}, \mathrm{CH}$, and $\mathrm{H})$ sorption properties of porous metalorganic tetrahedral and heterocuboidal polyhedra," Journal of the American Chemical Society, vol. 127, no. 19, pp. 7110-7118, 2005.

[44] J. Moriyama, H. Nishiguchi, T. Ishihara, and Y. Takita, "Metal sulfate catalyst for $\mathrm{CCl}_{2} \mathrm{~F}_{2}$ decomposition in the presence of $\mathrm{H}_{2} \mathrm{O}$," Industrial and Engineering Chemistry Research, vol. 41, no. 1, pp. 32-36, 2002.

[45] S. Y. Wan, YI. Z. Li, T. A. Okamura, J. Fan, W. Y. Sun, and N. Ueyama, "Syntheses, structures, and properties of two-dimensional honeycomb networks from the assembly of the tripodal ligand 2,4,6-Tris[4-(imidazol-1ylmethyl)phenyl]-1,3,5-triazine with metal salts," European Journal of Inorganic Chemistry, no. 20, pp. 3783-3789, 2003.

[46] Z. He, E. N. Q. Gao, Z. M. Wang, C. H. Yan, and M. Kurmoo, "Coordination polymers based on inorganic lanthanide(III) sulfate skeletons and an organic isonicotinate $\mathrm{N}$-oxide connector: segregation into three structural types by the lanthanide contraction effect," Inorganic Chemistry, vol. 44, no. 4, pp. 862-874, 2005.

[47] J. Reedijk, "The relevance of hydrogen bonding in the mechanism of action of platinum antitumor compounds," Inorganica Chimica Acta, vol. 198-200, pp. 873-881, 1992.

[48] D. Peak, R. G. Ford, and D. L. Sparks, "An in situ ATR-FTIR investigation of sulfate bonding mechanisms on goethite," Journal of Colloid and Interface Science, vol. 218, no. 1, pp. 289299, 1999.

[49] G. Tamasi and R. Cini, "Study of binary and ternary metal complexes containing the sulfato ligand: molecular models for selected non-catalytic sites in sulfurylase," Dalton Transactions, no. 14, pp. 2928-2936, 2003.

[50] C. Papatriantafyllopoulou, L. F. Jones, T. D. Nguyen et al., "Using pyridine amidoximes in 3d-metal cluster chemistry: a novel ferromagnetic Ni complex from the use of pyridine-2amidoxime," Dalton Transactions, no. 24, pp. 3153-3155, 2008.

[51] C. Papatriantafyllopoulou, G. Aromi, A. J. Tasiopoulos et al., "Use of the sulfato ligand in 3d-metal cluster chemistry: a family of hexanuclear nickel(II) complexes with 2-pyridylsubstituted oxime ligands," European Journal of Inorganic Chemistry, no. 18, pp. 2761-2774, 2007.

[52] C. G. Efthymiou, A. A. Kitos, C. P. Raptopoulou, S. P. Perlepes, A. Escuer, and C. Papatriantafyllopoulou, "Employment of the sulfate ligand in 3d-metal cluster chemistry: a novel hexanuclear nickel(II) complex with a chair metal topology," Polyhedron, vol. 28, no. 15, pp. 3177-3184, 2009.

[53] R. A. Coxall, S. G. Harris, D. K. Henderson, S. Parsons, P. A. Tasker, and R. E. P. Winpenny, "Inter-ligand reactions: in situ formation of new polydentate ligands," Journal of the Chemical Society, Dalton Transactions, no. 14, pp. 2349-2356, 2000.

[54] A. Altomare, G. Cascarano, C. Giacovazzo et al., "SIR92-a program for automatic solution of crystal structures by direct methods," Journal of Applied Crystallography, vol. 27, p. 435, 1993.

[55] G. M. Sheldrick, SHELXL-97, Program for the Refinement of Crystal Structures from Diffraction Data, University of Göttingen, Göttingen, Germany, 1997.

[56] P. Van der Sluis and A. L. Spek, "BYPASS: an effective method for the refinement of crystal structures containing disordered solvent regions," Foundations of Crystallography, vol. 46, no. 4, pp. 194-201, 1990.
[57] Oxford Diffraction, CrysAlis CCD and CrysAlis RED, version 1.171.32.15; Oxford Diffraction Ltd, Abingdon, UK, 2008.

[58] L. J. Farrugia, "WinGX suite for small-molecule single-crystal crystallography," Journal of Applied Crystallography, vol. 32, no. 4, pp. 837-838, 1999.

[59] I. J. Bruno, J. C. Cole, P. R. Edgington et al., "New software for searching the Cambridge Structural Database and visualizing crystal structures," Acta Crystallographica Section B, vol. 58, no. 3, pp. 389-397, 2002.

[60] K. Bradenburg, DIAMOND, Release 3.1f, Crystal Impact, GbR, Bonn, Germany, 2008.

[61] V. L. Pecoraro, A. J. Stemmler, B. R. Gibney et al., "Metallacrowns: a new class of molecular recognition agents," Progress in Inorganic Chemistry, vol. 45, pp. 83-177, 1997.

[62] C. Papatriantafyllopoulou, C. G. Efthymiou, C. P. Raptopoulou et al., "Initial use of the di-2-pyridyl ketone/sulfate "blend" in 3d-metal cluster chemistry: preparation, X-ray structures and physical studies of zinc(II) and nickel(II) cubanes," Journal of Molecular Structure, vol. 829, no. 1-3, pp. 176-188, 2007.

[63] G. S. Papaefstathiou, A. Escuer, F. A. Mautner et al., "Use of the di-2-pyridyl ketone/acetate/dicyanamide "blend" in manganese(II), cobalt(II) and nickel(II) chemistry: neutral cubane complexes," European Journal of Inorganic Chemistry, no. 5, pp. 879-893, 2005.

[64] C. G. Efthymiou, C. P. Raptopoulou, A. Terzis et al., "A systematic exploration of nickel(II)/acetate/di-2-pyridyl ketone chemistry: neutral and cationic tetranuclear clusters, and a novel mononuclear complex," European Journal of Inorganic Chemistry, no. 11, pp. 2236-2252, 2006.

[65] C. Papatriantafyllopoulou, C. P. Raptopoulou, A. Terzis, J. F. Janssens, S. P. Perlepes, and E. Manessi-Zoupa, "Reactions of nickel(II) sulfate hexahydrate with methyl(2-pyridyl)ketone oxime: two mononuclear sulfato complexes containing the neutral ligand," Zeitschrift fur Naturforschung, vol. 62, no. 9, pp. 1123-1132, 2007.

[66] M. Moragues-Cánovas, M. Helliwell, L. Ricard et al., "An $\mathrm{Ni}$, single-molecule magnet: synthesis, structure and lowtemperature magnetic behavior," European Journal of Inorganic Chemistry, no. 11, pp. 2219-2222, 2004.

[67] E. N. C. Yang, W. Wernsdorfer, S. Hill et al., "Exchange bias in Ni single-molecule magnets," Polyhedron, vol. 22, no. 14-17, pp. 1727-1733, 2003.

[68] A. Escuer, M. Font-Bardía, S. B. Kumar, X. Solans, and R. Vicente, "Two new nickel(II) cubane compounds derived from pyridine-2-methoxide $(\mathrm{Pym}): \mathrm{Ni}(\mathrm{Pym}) \mathrm{Cl}(\mathrm{CHOH})$ and $\mathrm{Ni}(\mathrm{Pym})(\mathrm{N})(\mathrm{CH} \mathrm{OH})$. Crystal structures and magnetic properties," Polyhedron, vol. 18, no. 6, pp. 909-914, 1999.

[69] E. N. C. Yang, W. Wernsdorfer, L. N. Zakharov et al., "Fast magnetization tunneling in tetranickel(II) single-molecule magnets," Inorganic Chemistry, vol. 45, no. 2, pp. 529-546, 2006.

[70] C. G. Efthymiou, C. P. Raptopoulou, A. Terzis et al., "A systematic exploration of nickel(II)/acetate/di-2-pyridyl ketone chemistry: neutral and cationic tetranuclear clusters, and a novel mononuclear complex," European Journal of Inorganic Chemistry, no. 11, pp. 2236-2252, 2006.

[71] C. G. Efthymiou, C. Papatriantafyllopoulou, N. I. Alexopoulou et al., "A mononuclear complex and a cubane cluster from the initial use of 2-(hydroxymethyl)pyridine in nickel(II) carboxylate chemistry," Polyhedron, vol. 28, no. 15, pp. 33733381, 2009. 
[72] A. Sieber, C. Boskovic, R. Bircher et al., "Synthesis and spectroscopic characterization of a new family of Ni spin clusters," Inorganic Chemistry, vol. 44, no. 12, pp. 4315-4325, 2005.

[73] K. Isele, F. Gigon, A. F. Williams et al., "Synthesis, structure and properties of $\left\{\mathrm{M}_{4} \mathrm{O}_{4}\right\}$ cubanes containing nickel(II) and cobalt(II)," Dalton Transactions, no. 3, pp. 332-341, 2007.

[74] M. A. Halcrow and G. Christou, "Biomimetic chemistry of nickel," Chemical Reviews, vol. 94, no. 8, pp. 2421-2481, 1994.

[75] A. J. Edwards, B. F. Hoskins, E. H. Kachab, A. Markiewicz, K. S. Murray, and R. Robso, "Synthesis, x-ray crystal structures, and magnetic properties of $\mathrm{Ni}$ complexes of a macrocyclic tetranucleating ligand," Inorganic Chemistry, vol. 31, no. 17, pp. 3585-3591, 1992.

[76] E. Jabri, M. B. Carr, R. P. Hausinger, and P. A. Karplus, "The crystal structure of urease from Klebsiella aerogenes," Science, vol. 268, no. 5213, pp. 998-1004, 1995.

[77] A. Escuer, R. Vicente, S. B. Kumar, and F. A. Mautner, "Spin frustration in the butterfly-like tetrameric $[\mathrm{Ni}(\mu-\mathrm{CO})($ aetpy) $]$ $[\mathrm{ClO}][$ aetpy $=(2$-aminoethyl $)$ pyridine $]$ complex. Structure and magnetic properties," Journal of the Chemical SocietyDalton Transactions, no. 20, pp. 3473-3477, 1998.

[78] J. M. Clemente, H. Andres, J. J. Borrás-Almenar et al., "Magnetic excitations in polyoxometalate clusters observed by inelastic neutron scattering: evidence for ferromagnetic exchange interactions and spin anisotropy in the tetrameric nickel(II) cluster $[\mathrm{Ni}(\mathrm{HO})(\mathrm{PWO})]$ and comparison with the magnetic properties," Journal of the American Chemical Society, vol. 121, no. 43, pp. 10021-10027, 1999.

[79] Z. E. Serna, L. Lezama, M. K. Urtiaga et al., "A dicubane-like tetrameric nickel(II) azido complex," Angewandte ChemieInternational Edition, vol. 39, no. 2, pp. 344-347, 2000.

[80] P. Venkateswara Rao, S. Bhaduri, J. Jiang, and R. H. Holm, "Sulfur bridging interactions of cis-planar Ni-S N coordination units with nickel(II), copper(I,II), zinc(II), and mercury(II): a library of bridging modes, including $\mathrm{Ni}(\mu$ SR)M rhombs," Inorganic Chemistry, vol. 43, no. 19, pp. 5833 $5849,2004$.

[81] K. T. Szacilowski, P. Xie, A. Y. S. Malkhasian et al., "Solid-state structures and magnetic properties of halide-bridged, faceto-face bis-nickel(II)-macrocyclic ligand complexes: ligandmediated interchanges of electronic configuration," Inorganic Chemistry, vol. 44, no. 17, pp. 6019-6033, 2005.

[82] X. López, M. Y. Huang, G. C. Huang et al., "Evennumbered metal chain complexes: synthesis, characterization, and DFT analysis of $[\mathrm{Ni}(\mu$-Tsdpda) $(\mathrm{H} \mathrm{O})]($ Tsdpda $=\mathrm{N}$ (p-toluenesulfonyl) dipyridyldiamido), $[\mathrm{Ni}(\mu$-Tsdpda $)]$, and related Ni string complexes," Inorganic Chemistry, vol. 45, no. 22, pp. 9075-9084, 2006.

[83] E. Carmona, E. Gutiérrez-Puebla, A. Monge, M. Paneque, and M. L. Poveda, "Unusual alkylidene-bridged complexes of nickel by $\alpha-\mathrm{H}$ abstraction from a nickelacycle. Crystal and molecular structure of [Ni (CHCMe-o-CH)Cl(PMe )], Journal of the Chemical Society, Chemical Communications, no. 3, pp. 148-150, 1991.

[84] J. Klingele, J. F. Boas, J. R. Pilbrow et al., "A $[2 \times 2]$ nickel(II) grid and a copper(II) square result from differing binding modes of a pyrazine-based diamide ligand," Dalton Transactions, no. 6, pp. 633-645, 2007.

[85] F. Meyer, M. Konrad, and E. Kaifer, "Novel $\mu$-coordination of urea at a nickel(II) site: structure, reactivity and ferromagnetic superexchange," European Journal of Inorganic Chemistry, no. 11, pp. 1851-1854, 1999.
[86] K. Yamada, S. Yagishita, H. Tanaka et al., "Metal-complex assemblies constructed from the flexible hinge-like ligandHbhnq: structural versatility and dynamic behavior in the solid state," Chemistry - A European Journal, vol. 10, no. 11, pp. 2647-2660, 2004.

[87] M. Bell, A. J. Edwards, B. F. Hoskins, E. H. Kachab, and R. Robson, "Synthesis and X-ray crystal structures of Ni and Zn complexes of a macrocyclic tetranucleating ligand," Journal of the American Chemical Society, vol. 111, no. 10, pp. 3603-3610, 1989.

[88] M. Alexiou, C. Dendrinou-Samara, C. P. Raptopoulou, A. Terzis, V. Tangoulis, and D. P. Kessissoglou, "A cationic tetranuclear $[\mathrm{Ni}(\mathrm{MeOH})$ (pko)] cluster showing antiferroand ferromagnetic features," European Journal of Inorganic Chemistry, no. 19, pp. 3822-3827, 2004.

[89] V. V. Pavlishchuk, S. V. Kolotilov, A. W. Addison et al., "A tetrameric nickel(II) "chair" with both antiferromagnetic internal coupling and ferromagnetic spin alignment," Angewandte Chemie-International Edition, vol. 40, no. 24, pp. 4734-4737, 2001.

[90] G. Psomas, C. Dendrinou-Samara, M. Alexiou et al., "The first fused dimer metallacrown $\mathrm{Ni}_{2}^{\mathrm{II}}(\mathrm{mcpa})_{2}\left(\mathrm{CH}_{3} \mathrm{OH}\right)_{3}\left(\mathrm{H}_{2} \mathrm{O}\right)$ $\left[12-\mathrm{MC}_{\mathrm{Ni}^{\mathrm{II}} \mathrm{N}_{(\text {shi)2(pko)2 }}}-4\right]\left[12-\mathrm{MC}_{\mathrm{Ni}^{\mathrm{II}} \mathrm{N}_{(\text {shi)3(pko) }}}-4\right]$," Inorganic Chemistry, vol. 37, no. 26, pp. 6556-6557, 1998.

[91] G. Psomas, A. J. Stemmler, C. Dendrinou-Samara et al., "Preparation of site-differentiated mixed ligand and mixed ligand/mixed metal metallacrowns," Inorganic Chemistry, vol. 40, no. 7, pp. 1562-1570, 2001.

[92] M. Alexiou, I. Tsivikas, C. Dendrinou-Samara et al., "High nuclearity nickel compounds with three, four or five metal atoms showing antibacterial activity," Journal of Inorganic Biochemistry, vol. 93, no. 3-4, pp. 256-264, 2003.

[93] P. Chaudhuri, M. Winter, U. Flörke, and H. J. Haupt, "An effectively diamagnetic oximato-bridged asymmetric dinuclear copper(II) complex with a $\mathrm{Cu}(\mathrm{II}) \mathrm{I}$ bond," Inorganica Chimica Acta, vol. 232, no. 1-2, pp. 125-130, 1995.

[94] C. Papatriantafyllopoulou, C. P. Raptopoulou, A. Terzis, E. Manessi-Zoupa, and S. P. Perlepes, "Investigation of the zinc chloride/methyl(2-pyridyl)ketone oxime reaction system: a mononuclear complex and an inverse 12-metallacrown-4 cluster," Zeitschrift fur Naturforschung, vol. 61, no. 1, pp. 3746, 2006.

[95] J. J. López-Garriga, G. T. Babcock, and J. F. Harrison, "Factors influencing the $\mathrm{C}=\mathrm{N}$ stretching frequency in neutral and protonated Schiff's bases," Journal of the American Chemical Society, vol. 108, no. 23, pp. 7241-7251, 1986.

[96] A. B. P. Lever and E. Mantovani, "The far-infrared and electronic spectra of some bis-ethylenediamine and related complexes of copper(II) and the relevance of these data to tetragonal distortion and bond strengths," Inorganic Chemistry, vol. 10, no. 4, pp. 817-826, 1971.

[97] K. Nakamoto, Infrared and Raman Spectra of Inorganic and Coordination Compounds, John Wiley \& Sons, New York, NY, USA, 4th edition, 1986. 


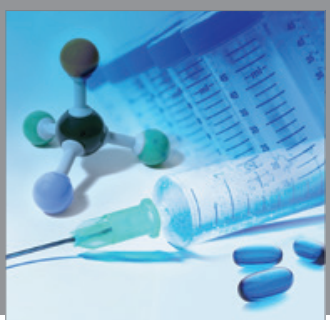

International Journal of

Medicinal Chemistry

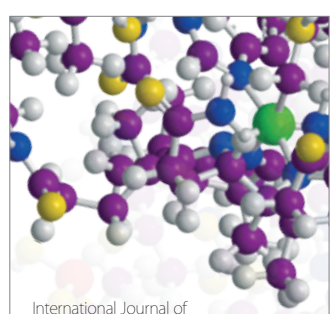

Carbohydrate Chemistry

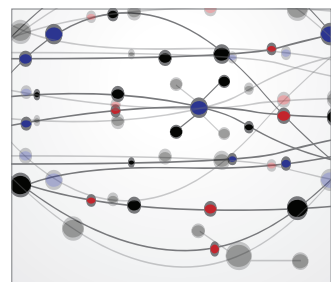

The Scientific World Journal
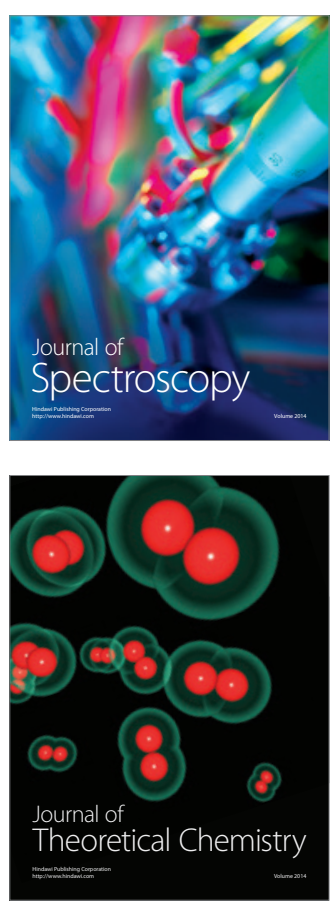
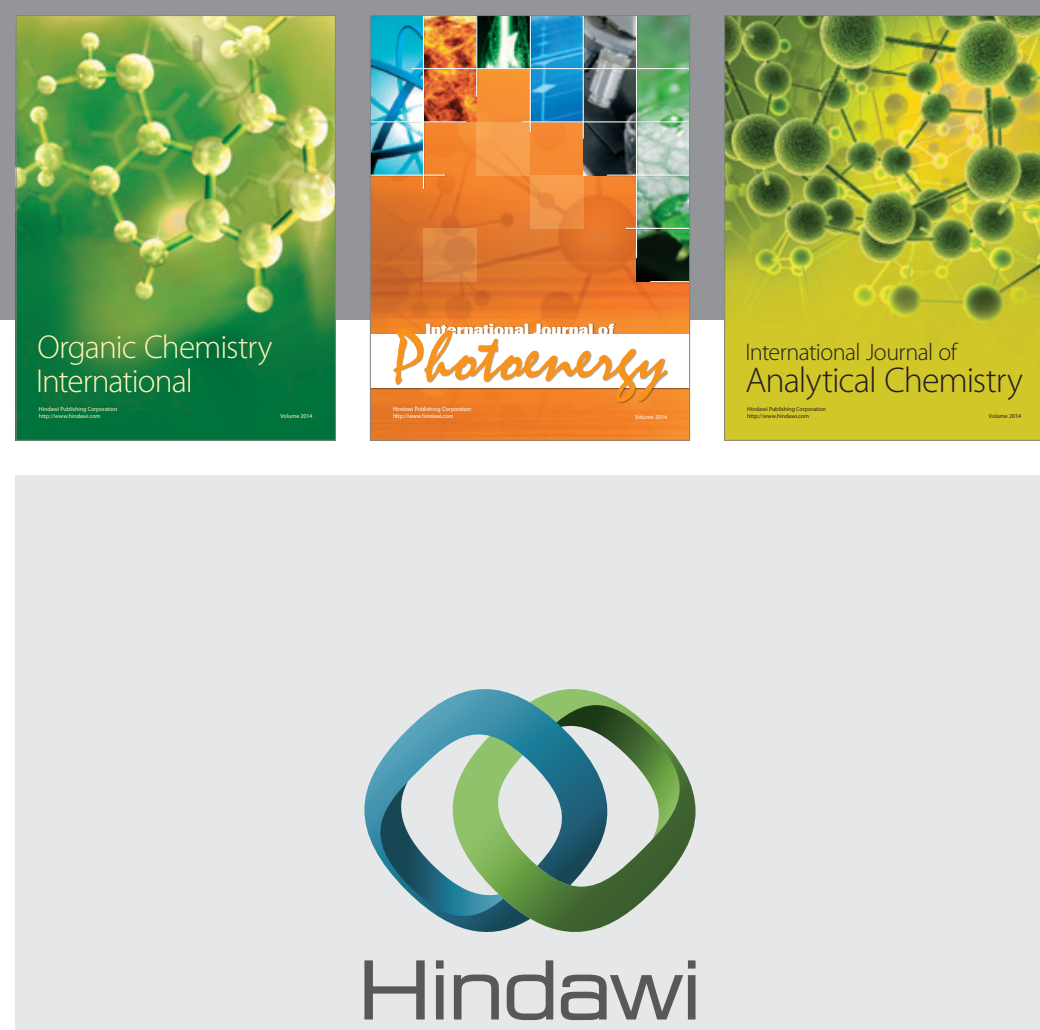

Submit your manuscripts at

http://www.hindawi.com
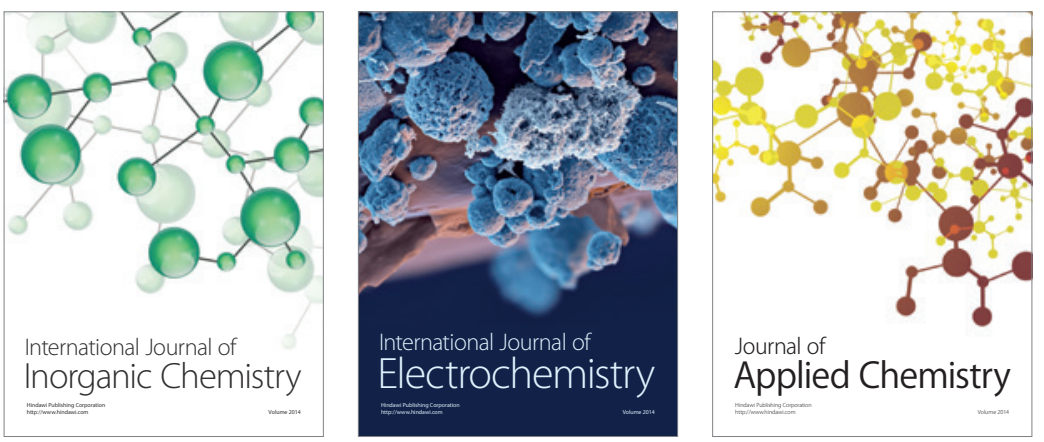

Journal of

Applied Chemistry
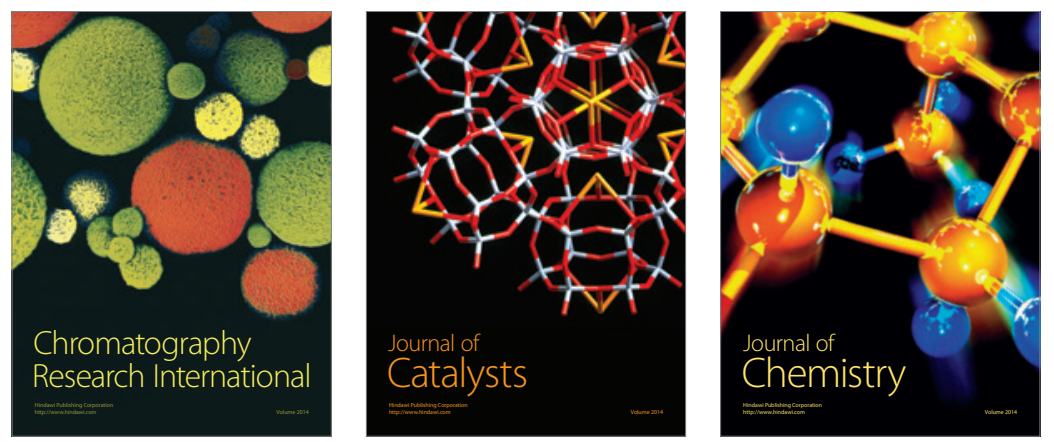
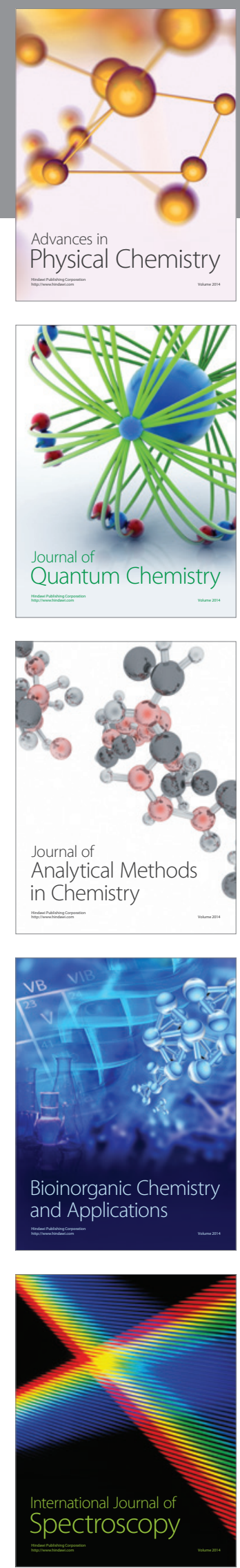